\title{
Time for a National Security Strategy
}

\section{Author/s: Chris Rothery}

To cite this article: Rothery, C. (2019). Time for a National Security Strategy. National Security Journal, 1(1), 5-15. doi:10.36878/nsj201901.05

To link to this article: https://doi.org/10.36878/nsj201901.05

View CrossRef data: https://search.crossref.org/?q=10.36878\%2FNSJ201901.05\# 


\title{
TIME FOR A NATIONAL SECURITY STRATEGY
}

\author{
Chris Rothery ${ }^{1}$
}

\begin{abstract}
The global environment is becoming more complex and aggressive, with numerous threats from, undesirable foreign influence, traditional, political and economic espionage, organised crime, bio-security; natural disasters, pandemics, and terrorism. New Zealand has experienced all of these. With this extensive, but by no means exhaustive list, the question must be asked, why then does New Zealand not have a national security strategy, one that focusses the nation's resources on reducing these threats and risks? A national security strategy is not one that needs to give away all of the state's secrets, it can simply be a framework for collaboration across the government on national security. It should be the basis for a joined up approach across government to crisis management and conflict. What New Zealand currently has is a collection of unrelated documents with varying levels of connectivity to national security - the only forward looking documents are those from the New Zealand Defence Force. New Zealand needs to adopt a forward looking strategic approach to national security and develop a national security strategy. This strategy needs to align the policies of different government agencies towards a cohesive national security framework that targets our most important threats, so that the harm they cause does not eventuate or is mitigated.
\end{abstract}

The foundation of the New Zealand national security system is the National Security System Handbook 2015, a document more akin to a guide of what happens in the event of an emergency. No overarching strategic document exists that coordinates all the elements of state power towards a common goal of national security. New Zealand's national security is a whole-of-government approach, yet there is no whole-of-government direction as to the delivery and development of security capabilities. This article will examine the state of the national security system, reviewing the current national security related documents and examining the nature of their linkages and connections. National security is an essential part of allowing the citizens of New Zealand the opportunity to go about their daily business free from fear. New Zealand needs a national security strategy, one that provides direction for the whole-of-government approach to national

$1 \quad$ Chris Rothery is a Senior Lecturer in Defence Studies at the Centre for Defence and Security Studies, Massey University. Contact C.Rothery@massey.ac.nz. 
security and one that provides direction on the coordination of national security capabilities. This article will propose how a national security strategy could be formulated, with an emphasis on the coordination of strategic documents that are nested under an overarching strategy.

\section{New Zealand's National Security Framework}

The role of the New Zealand Government is to provide security and ensure the territorial integrity of New Zealand. The government must protect the institutions that sustain confidence, promote the achievement of national goals and through providing security, support the pursuit of economic opportunities, the provision of international relationships and help to build a sense of community. ${ }^{1}$ The New Zealand Government defined national security as 'the coordination which permits the citizens of a state to go about their daily business confidently free from fear and able to make the most of the opportunities to advance their way of life. It encompasses preparedness, protection and preservation of people, property and information, both tangible and intangible. ${ }^{2}$ The government recognised that New Zealand's security is increasingly linked to security in other countries and therefore seeks to reinforce its national security through partnerships and by supporting an international rules-based order. ${ }^{3}$ New Zealand's approach to national security is provided through an 'all-of-government' National Security System (NSS) that has tended to react to events, rather than systematically bringing a forward-looking approach to risk reduction. ${ }^{4}$ It is a system that emphasises risks and a resilience-based methodology. It is a reactionary approach with a system centrally controlled by government. It is the responsibility of DPMC to coordinate New Zealand's national security framework.

The NSS is designed to ensure that the security architecture performs as intended and the details of how it operates is contained within the NSS Handbook. When a crisis event occurs that challenges national security, the NSS is activated. The response to the crisis is built around the threat that occurs, therefore, its makeup will vary depending on the threat and has varying levels of coordination. At the executive level, the Official's Committee for Domestic and External Coordination (ODSEC) provides strategic advice to the Prime Minister, and other Ministers, on such matters as priorities for resource and capability allocation. An example where ODSEC provided guidance was during the 2015 terrorist attacks in Paris. ODSEC provided advice on possible implications for New Zealand citizens in France and also any threats to New Zealand. ${ }^{5}$ Informing the NSS and ODSEC is the Security and Intelligence Group (SIG). SIG provides assessments to the Prime Minister, senior ministers and senior officials on security events and security related developments. SIG performs a collaborative leadership role within the wider New Zealand intelligence community and with the Intelligence and Assessments Bureau, coordinates all the source assessments for response and advice decision making. ${ }^{6}$ 
What is not present is a cohesive national security strategy, or any document that can be considered a central directive that provides the government's intent on national security. Instead the strategies and policy documents of individual government agencies are relied on; these significantly differ and are not connected to each other in any cohesive manner. This is concerning since the approach to national security is a whole-of-government one.

\section{Intelligence and Security}

The documents and policies relating to the collection of intelligence in New Zealand are restricted to legislation and information on the intelligence agencies contained on their public websites. This is due to the confidential nature of their role in supporting national security. The responsibility of providing this information falls to the intelligence agencies, which in New Zealand are the Government Security and Communications Bureau (GCSB) and the New Zealand Security Intelligence Service (NZSIS). The collection of intelligence is conducted covertly and through concealed methods, which in a free and democratic nation such as New Zealand presents a number of issues. The issue of balancing the requirement for effective intelligence gathering to support national security and the basic human right of freedom and liberty was addressed in Intelligence and Security in a Free Society: Report of the First Independent Review of Intelligence and Security in New Zealand conducted in 2015 by Hon Sir Michael Cullen, KNZM and Dame Patsy Reddy, DNZM. The review was called for after concerns were raised about the legislation that the GCSB and the NZSIS operated under. ${ }^{7}$ The review was primarily focused on the legislation of intelligence and security: however, it did make recommendations for changes to the role and function of the two organisations. As a result of the 2015 review into the intelligence and security legislation, new legislation was quickly released, amending many of the issues identified. The Intelligence and Security Act 2017 established a new legislative framework for the intelligence agencies to operate within and also ensured that the intelligence agencies performed in accordance with New Zealand law and all international human rights conventions. ${ }^{8}$ The 2017 Act remedied the barriers in previous legislation that prevented intelligence and security agencies sharing information with each other. ${ }^{9}$

\section{Civil Defence and Emergency Management}

The response to natural disaster, which is considered a threat to the population going about their daily business free from fear and want, falls to the Ministry of Civil Defence and Emergency Management (MCDEM). Two key documents outline its approach to emergency management: the Civil Defence and Emergency Management Act 2002, and the National CDEM Plan 2015. In the event of an emergency, such as an earthquake, weather event, or the failure of infrastructure, MCDEM will lead the national response and recovery efforts. It does this through working with local government and the regional CDEM Groups to ensure that the right resources and services are available to the im- 
pacted communities. The Civil Defence and Emergency Management Act 2002, is the legislation that provided the guidance to the national, regional and local organisations for their role and authority during an event. An important document that brings the legislation of the Civil Defence and Emergency Management Act 2002 into practice is the $\mathrm{Na}$ tional CDEM Plan 2015. The plan "aims to integrate and align agencies CDEM planning and related operational activities at the national level". ${ }^{10}$ The National CDEM Plan 2015 is effectively an operational execution document providing information to a wide range of government departments and businesses for the coordination at the national level. It articulated the key responsibilities for each agency, the operational arrangements with other agencies and what function they are expected to make in response to an event.

\section{Counter Terrorism}

The recent terrorist attack in New Zealand demonstrated how the violent acts of even just one person can have significant impacts on the citizens of the whole country. Prior to the events of 15 March in Christchurch, New Zealand had experienced direct terrorist attacks, but few of them have been retained in the nation's collective memory. The Rainbow Warrior bombing in 1985, as well as the earlier bombings of the Wellington Trades Hall and the National Police Computer Centre in Wanganui, were all domestic terrorist attacks. While New Zealand has developed some legislation and policy surrounding the threat of terrorism, these documents are old and have not kept pace with the rapid evolution and development of global terrorism and its risks to New Zealand. Under the seven overarching national security objectives contained within the NSS Handbook, terrorism is not directly referred to. Instead it comes under the objective of "protecting the physical security of New Zealand Citizens". ${ }^{11}$ Apart from the legislation that provides organisations the authority to manage terrorism, there lacks a strategic plan that expresses how this risk will be mitigated by New Zealand security organisations. There is a section on Counter Terrorism (CT) in the National CDEM Plan 2015. It articulates how the strategic aim of New Zealand's CT effort is to ensure that New Zealand is 'neither the victim nor the source of an act of terrorism. ${ }^{12}$ It sets out how the Combined Threat Assessment Group (CTAG), within the NZSIS, assesses terrorist activities and how this is then disseminated to other agencies. There is no single government agency that is identified as being solely responsible for CT, instead CDEM and the National Security System Directorate within DPMC, appear to be the two agencies responsible for the delivery of CT coordination. In addition, the Ministry of Justice (MJ) and the Ministry of Foreign Affairs and Trade (MFAT) are the two agencies responsible for administering the Terrorism Suppression Act 2002 and the New Zealand Police are the lead agency for any terrorist threat that emerges within New Zealand. ${ }^{13}$ This dispersed nature of responsibility between the NSS, CDEM, MFAT, the New Zealand Police and the MJ is a very messy approach to dealing with any terrorist threat. With all these different agencies holding different responsibilities, it is difficult to see how the CT framework can be effective. 


\section{Cyber Security}

The evolution of global trade and communication has increased global interconnectedness, where states are now connected through a vast number of complex networks. This comes with significant threats to New Zealand's national security. With estimates that cyber-crime cost the global economy USD 6.6 trillion last year, it is vital for the New Zealand economy that New Zealand has an effective cyber-security framework. ${ }^{14}$ The coordination of cyber-security sits within DPMC under SIG. The National Cyber Police Office (NCPO) is responsible for the development of cyber security policy advice to government. NCPO reports formally to the Minister of Broadcasting Communications and Digital Media, ${ }^{15}$ all of which broadens the span of organisations with input or responsibilities into the national security framework. It would make more sense for organisations that are responsible for national security to have tighter reporting lines to fewer ministers, rather than the spread that is becoming evident. New Zealand has a whole-of-government approach to national security, but this does not mean that the whole-of-government needs to be involved in every aspect of it. A better formula would be for one organisation to be responsible for cyber-security that can reach out to resources from the whole-of-government and the private sector.

Two organisations from two different agencies are responsible for the operational response to a cyber-attack. The National Cyber Security Centre (NCSC) within GCSB is responsible for providing protective cyber services and guidance to 'organisations of national significance,' as well as taking the lead on cyber incidents at the national level. ${ }^{16}$ Within the Ministry of Business, Innovation and Employment (MBIE), the Computer Emergency Response Team (CERT) provides a lower level of cyber security advice to organisations that do not require the level of specialist skills that the NCSC possess. In addition to these organisations, the Protective Security Requirements (PSR) is an organisation that is supported by both the GCSB and the NZSIS. PSR sponsors the New Zealand Information Security Manual, which sets out the guidelines for the protection of information in the cyber domain. Additionally the New Zealand Cyber Security Strategy 2015 articulated how the government will adopt a whole-of-government approach to whole-of-society cyber security. This document recognises the need for close partnerships with the private sector and non-government organisations, and it details how these connections will be made (New Zealand Government 2015). Unfortunately, the eight-page long strategy, which is mostly filled with diagrams and pictures, does not fit into the category of a comprehensive strategic document. In 2018 the Minister of Broadcasting, Communications and Digital Media released an Action Plan for the refresh of New Zealand's Cyber Security Strategy, due to an upward trend in security threats. ${ }^{17}$ The New Zealand cyber-security framework is quite broad, however, its control suffers from being dispersed across many different organisations. There are five different agencies that have a cyber-security responsibility: NCPO, NCSC, CERT, PSR and Connect Smart. These agencies report to or are controlled by five government min- 
istries or departments: NZSIS, GCSB, MBIE, DPMC and the Minister of Broadcasting Communications and Digital Media. This wide framework aligns to the whole-of-government approach to security but it is cumbersome and a more effective system for the control of cyber-security could be developed.

\section{Defence}

In recent years there has been a flurry of documents released relating to defence. There was the Defence White Paper 2016, the Strategic Defence Policy Statement 2018, and most recently the Defence Capability Plan 2019, all released against a backdrop of changes to the international environment and to align defence policy with the New Zealand government's national security and foreign policy priorities. These documents, under different governments, articulated the role of the New Zealand Defence Force (NZDF), the strategic environment and mapped out future capability investment for the NZDF. A positive aspect of these documents is that the Defence White Paper 2016 and the Strategic Policy Statement 2018 both discuss the seven overarching national strategic objectives listed in the NSS Handbook, demonstrating a rare link within New Zealand's national security documents with central security policy.

The proceeding chapters of the Defence White Paper 2016, the Strategic Defence Policy Statement 2018 and the Defence Capability Plan 2019 articulated the roles and tasks for the NZDF as well as detailing future capability development. According to James Rolfe, the purpose of a white paper should be to articulate policy based on significant changes to the environment and allow for capability development. ${ }^{18}$ However, what appears in the DWP 2016 is a list of current capabilities, a justification for their purchase and how they are employed. The Defence White Paper 2016 is therefore not the forward-looking document it should be. It discusses the emerging security threats to New Zealand with no connection to the future capabilities required by the NZDF to meet these new challenges. Damien Rogers argued that the Defence White Paper 2016 fails to consider the relationships between the State, economic and social factors that shape armed conflict and does not provide the necessary analysis for the major security challenges facing New Zealand. ${ }^{19}$ Likewise the Strategic Defence Policy Statement 2018 is a continuation of the Defence White Paper 2016. It defines the NZDF's capabilities, which have hardly changed since the DWP 2016 was released, and the intent of future capability development. The Defence Capability Plan 2019, is just a continuation of the previous two documents and provides some more detail on specific spending, however, it has toned down the aggressive rhetoric towards China and Russia. These documents appear to contain more of the same content, with no changes to the Cold War era structures or to capabilities of the NZDF to meet the changing threats to New Zealand national security. 


\section{Criticisms of the New Zealand national security framework}

The New Zealand national security framework is based around responding to events and having the measures in place for an effective response, but it does not contain a forward-looking strategy. There are individual agency documents that do have forward-looking elements to them, such as the Defence White Paper 2016 and Biosecurity 2025 , however, these are not connected to each other or any other agency plan. The intent behind a national security strategy would be to provide government agencies with centralised and common direction and guidance, so when developing their national security capabilities, they are coordinated with other agencies. ${ }^{20}$ There is very little in the way of strategic thinking when it comes to New Zealand's approach to national security. ${ }^{21}$ MFAT has reduced its Strategic Policy Division, highlighting that there does not appear to be an emphasis for developing strategic direction for national security. The whole-of-society approach to national security is based around collaboration between government agencies themselves and between them and the private sector. However, there is no strategy for how this will occur, or how the government intends to develop a more inclusive approach.

It was noted by Demos, a London-based think tank specialising in social policy, that the boundaries between domestic and international politics have become blurred and interconnected and therefore it is necessary for the UK to take a networked approach to security strategy. ${ }^{22}$ It should be no different for New Zealand. Additionally, a national security strategy should include the conduct of a comprehensive review of the strategy at regular intervals. At present the reviews are ad hoc and for one particular piece of legislation or plan at a time. The Intelligence and Security Review was conducted in 2017, yet there has been no review of the Terrorism Suppression Act 2002, which are two legislative areas that should be viewed as interconnected in the current threat environment. The National CDEM Plan 2015 was reviewed in 2017, two years after its release, however there has been no review of the National Security System Handbook since it was released in 2016. A national security strategy would develop a timeframe for the periodic review of all national security documents.

It has been widely acknowledged within the documents and plans reviewed, that the security environment is evolving and the threats faced are broadening. It would make sense therefore to develop a framework that goes beyond the current focus of government agencies involved in national security. The Cold War era saw security provided primarily by defence, police and the intelligence agencies. Now the responsibility for security has expanded to include a range of different agencies that can respond to a wide range of threats, but it should also include private business in the national security architecture. Additionally, the referent object of national security used to be the state, its territory, borders and institutions. However, with states now developing a framework for security based on the broader concept of human security, the focus of national 
security has to expand. For this to be achieved, it is necessary to widen the span of organisations involved in national security planning to include the private sector, as well as potentially the general public. The need for an increase in the private-public sector dialogue is articulated by Professor Rouben Azizian, who argued that businesses should be more vocal pre-crisis, rather than only becoming involved after an event has occurred. ${ }^{23}$ This view is also championed by Captain David Morgan in his recent address to Massey University's National Security Conference in 2018, where he suggested that major companies, such as Air New Zealand and Fonterra, need to be actively involved in the national security dialogue. ${ }^{24}$ Given that the protection of the economy is one of the seven objectives of New Zealand's national security, it would make sense to have a more inclusive environment for the private sector to be involved in the development of a security strategy.

For New Zealand's national security framework to be effective it is necessary that the ideas of how the state will provide security to the population and what is required of them, is effectively communicated. However, the NSS Handbook is a little-known publication, with one prominent business leader commenting that he "didn't know about it until [he] was asked for an interview." ${ }^{25}$ Even the National CDEM Plan 2015 suffers from the same anonymity. Furthermore there is little public discussion in New Zealand on the subject, meaning that security is hardly in the consciousness of the population. Excepting key crises, the only time there has been significant public debate on security matters is when there is an outcry over additional funding for a security agency such as the $\mathrm{NZDF}^{26}$ or as a result of an agency conducting an unlawful operation. ${ }^{27}$ Although New Zealand has seen an increase in security concerns over the last decade,$^{28}$ public opinion lists the two main security threats that New Zealanders fear as Identity Theft and Credit Card Fraud..$^{29}$ These are not significant national security threats and are not among the risks identified in government discourse.

\begin{tabular}{|c|c|c|c|c|c|c|c|}
\hline & 2002 & 2008 & 2015 & 2016 & 2017 & 2018 & 2019 \\
\hline \multirow{4}{*}{$\frac{. \overline{0}}{\overline{0}}$} & $\begin{array}{l}\text { Terrorism } \\
\text { Suppression } \\
\text { Act }\end{array}$ & \multirow[t]{4}{*}{$\begin{array}{l}\text { Policing } \\
\text { Act }\end{array}$} & $\begin{array}{l}\text { National } \\
\text { CDEM Plan }\end{array}$ & Biosecurity 2025 & \multirow[t]{4}{*}{$\begin{array}{l}\text { Intelligence } \\
\text { and Security } \\
\text { Act }\end{array}$} & \multirow[t]{4}{*}{$\begin{array}{l}\text { Strategic } \\
\text { Defence Policy } \\
\text { Statement }\end{array}$} & \multirow[t]{4}{*}{$\begin{array}{l}\text { Defence } \\
\text { Capability } \\
\text { Plan }\end{array}$} \\
\hline & \multirow{3}{*}{$\begin{array}{l}\text { Civil } \\
\text { Defence and } \\
\text { Emergency } \\
\text { Management } \\
\text { Act }\end{array}$} & & \multirow{3}{*}{$\begin{array}{l}\text { Cyber } \\
\text { Security } \\
\text { Strategy }\end{array}$} & $\begin{array}{l}\text { National Security } \\
\text { System Handbook }\end{array}$ & & & \\
\hline & & & & Defence White Paper & & & \\
\hline & & & & $\begin{array}{l}\text { Report of the First } \\
\text { Independent Review of } \\
\text { Intelligence and Securi- } \\
\text { ty in New Zealand }\end{array}$ & & & \\
\hline
\end{tabular}

Table 1: Reviewed New Zealand security document's release dates. This table demonstrates the random and uncoordinated nature of the New Zealand national security framework. There is a lack of synchronisation between the organisations and a lack of a central document to work from. 


\section{Conclusion}

A New Zealand national security strategy should not be seen as insurmountable. A strategy is something very common in the private sector, and many argue that organisations without a clear path for the future face an uncertain one. Simply put, a national security strategy will guide New Zealand's national security organisations and synchronise their actions. A national security strategy is a living document, it needs to change with the environment, nor should it be tied to a specific threat, but instead be moored and adaptable to the geopolitical situation. As threats evolve or change, then alterations can be made to the strategy. It should not just focus on the military, but on all sectors of government that deliver elements of national security. Linked to New Zealand's foreign policy strategy, the national security strategy establishes the baseline for what New Zealand will focus on for the delivery of security, what the most salient threats are and what capabilities are needed to meet these threats. This strategy would then be used by the various government departments to develop their own specific strategies and capability plans.

The development of a national security strategy is not the end game. The national security strategy should be the lead document in the hierarchy of national security documents. It will provide the overall guidance for the agencies and provide the framework for them to base their strategies upon. It is essential for effective strategy development that the government agencies responsible for national security nest their own strategies within this overarching document, something that the current framework lacks. There needs to be a logical sequence and over-arching structure in the way in which the different agency strategies are produced. The national security strategy should also provide a timeframe for when each agency is required to release their own strategies and operational plans. The irregular manner in which agencies develop their plans demonstrates that the current national security framework is haphazard and does not have a coherent approach.

National security matters. It provides the citizens of the state with not only physical security and protection against threats, but also the feeling of security, so they are comfortable in the knowledge that there is a system in place for their safety. A national security strategy is not a fool-proof guarantee that nothing will ever happen, instead it is a method of synchronising all parts of government into a common system and focus. A strategy allows for the allocation of resources into the right areas and focuses the different parts the state's power for a collective effort. New Zealand relies upon a responsive national security system, which to date - when tested, it has operated very well. But waiting for a crisis to occur is not a sustainable plan. A whole-of-government approach needs a whole-of-government strategy. A national security strategy needs to have an effective execution, one that continually reviews and updates the strategy where needed and one that is supported by an independent review system. We cannot be dis- 
missive about national security, and we must make every possible attempt to strengthen ourselves and put the nation in the best possible position for risk mitigation. The first step to this is a national security strategy.

1 Department of the Prime Minister and Cabinet, Briefing for Incoming Minister for National Security and Intelligence. (Wellington: Government of New Zealand, 2017).

2 Government of New Zealand. 2017. "National Security." The Intelligence and Security Act 2017 Fact Sheet No. 3.

3 Broad, Howard. 2017. "The New Zealand national security system" In New Zealand National Security: Challenges, Trends and Issues, eds., William Hoverd, Nick Nelson and Bradley Carl., (Massey University Press, Albany, 2017), pp.147-164.

4 Department of the Prime Minister and Cabinet. Briefing for Incoming Minister for National Security and Intelligence.

5 Department of Prime Minister and Cabinet, National Security System Handbook (Government of New Zealand, August 2016).

6 Department of the Prime Minister and Cabinet, Briefing for Incoming Minister for National Security and Intelligence.

7 Michael Cullen and Patsy Reddy, Intelligence and Security in a Free Society. Report of the First Independant Review of Intelligence and Security in New Zealand, (Wellington: New Zealand Government, 2016).

8 Parlimentary Counsel Office, "Intelligence and Security Act 2017." Public Act 2017 No 10., (Government of New Zealand, 28 March 2017).

9 Cullen and Reddy, Intelligence and Secuirty in a Free Society.

10 Ministry of Civil Defence and Emergency Management, National CDEM Plan 2015, (Wellington, 2015).

11 National Security System Handbook, 2016.

12 Ibid.

13 Ibid.

14 Nick Nelson, "Enhancing cybersecurity through talent management," Line of Defence Magazine, (Autumn 2018). Available at https://defsec.net.nz/2018/03/20/enhancing-cybersecurity-talent/.

15 Department of Prime Minister and Cabinet, National Cyber Policy Office, 18 June 2018. Available at https://www.dpmc.govt.nz/our-business-units/security-and-intelligence-group/national-cyber-policy-office.

16 New Zealand Government, About Us, 2017. Available at https://www.ncsc.govt.nz/about-us/working-with-cert-nz/.

17 Minister of Broadcasting, Communications and Digital Media, Refresh of New Zealand's Cyber Security Strategy and Action Plan, (Wellington: New Zealand Government, 2018).

18 James Rolfe, Defending New Zealand: A Study of Structures, Processes and Relationships, (Wellington: Institute of Policy Studies, 1993).

19 Damien Rogers, "New Zealand Security Intellectuals," New Zealand National Secuirty: Challenges, Trends and Issues, ed Nick Nelson, Carl Bradley and William Hoverd, (North Shore: Massey University Press, 2017), pp.308-325.

20 Terry Johanson, "New Zealand's national security coordination" New Zealand National Security: Challenges, Trends and Issues, eds Nelson, et al., 237-253.

21 Rogers, pp.308-325.

22 Demos Report, The case for a national security strategy, (London: Demos, 2007), available at https://www.demos.co.uk/files/Demos_report_the_case_for_a_national_security_strategy.pdf.

23 "Insight: we need a private-public sector dialogue on security," New Zealand Security Magazine, (August, 2017), pp.1-5. 
24 David Morgan, 'Private Sector Security', second National Security Conference, Massey University, 16 April, 2018.

25 William Durning (CEO, Waikato Chamber of Commerce), in discussion with the author, 22 November 2017.

26 Chris Trotter, "How many houses could we get for \$20 billion spend on defence," stuff.co.nz, 30 June 2016. Available at https://www.stuff.co.nz/national/politics/opinion/80986483/chris-trotter-how-many-houses-could-we-get-for-20-billion-spent-on-defence

27 "Three boatloads of asylum seekers headed to New Zealand: Australia", New Zealand Herald, 23 January 2018. Available at https://www.nzherald.co.nz/nz/news/article.cfm?c_id=1\&objectid=11980067

28 Howard Broad, "The New Zealand national security system," New Zealand National Security: Challenges, Trends and Issues, eds Nelson et al., (North Shore: Massey University Press, 2017) pp.147-164.

29 Homeland Security News, Line of Defence Magazine, 1:4 (2017), p.46. 